\title{
Water residence time in the Włocławek dam reservoir (the Vistula river, Poland) affects its macrozoobenthos structure
}

\author{
Daria Mimier $^{1}$, Elżbieta Żbikowska ${ }^{2}$ and Janusz Żbikowski ${ }^{1, *}$ \\ ${ }^{1}$ Department of Hydrobiology, Faculty of Biology and Environmental Protection Nicolaus Copernicus University, Toruń, Poland \\ ${ }^{2}$ Department of Invertebrate Zoology, Faculty of Biology and Environmental Protection, Nicolaus Copernicus University, Torun, Poland
}

Received: 27 July 2017; Accepted: 14 May 2018

\begin{abstract}
The aim of our study was to compare the macrozoobenthos structure as well as water and organic matter content of the bottom sediments of two hydrologically different zones of a strongly fluvial the Włocławek Dam Reservoir. Samples were collected from the Włocławek Dam Resevoir at six sites. Three of them were located in the upper, rheolimnic part (URP) of the reservoir and three others in its lower, limnetic part (LLP). Water transparency, sediment water content and organic matter content in the sediments were higher in the LLP. The higher number of taxa and diversity of macrozoobenthos were found in the URP of the reservoir. The density of bottom fauna was slightly higher in the LLP $\left(90,990\right.$ ind. $\mathrm{m}^{-2}$ ) than in the UPR $\left(73,486\right.$ ind $\left.\mathrm{m}^{-2}\right)$, while the significantly higher biomass of macrozoobenthos was found in the URP of the reservoir $\left(2314 \mathrm{~g} \cdot \mathrm{m}^{-2}\right)$ than in the LLP $\left(336 \mathrm{~g} \cdot \mathrm{m}^{-2}\right)$. The dominant taxa of Oligochaeta and Chironomidae larvae did not show significant differences in the density between both zones. Some taxa were found only in the URP. In this zone, significantly higher densities of other taxa were observed. The only species with greater abundance in the LLP was Potamothrix hammoniensis (Oligochaeta). Due to the very short water residence time, the differences in the parameters under study between the URP and the LLP of the reservoir were smaller as well as the abundance of the macrozoobenthos was distinctly higher than in other reservoirs.
\end{abstract}

Keywords: Rheolimnic lowland dam reservoir / bottom sediments / macrozoobenthos / water flow

\section{Introduction}

Natural fluvial ecosystems belong to the most diverse, but also the most degraded and threatened environments in the world (Dudgeon, 2010; Humphries et al., 2014). Impoundment exerts a very high influence on the river functioning. It leads to disrupting its continuity and formation of dam reservoirs (Ward and Stanford, 1983; Olden and Naiman, 2010). These constructions are present on more than a half of the world's large rivers and their number is still increasing (Richter et al., 2003). On one hand, such stream regulation is necessary and unavoidable, due to social and economic issues, such as energy generation, flood control or water supply. But on the other hand, it has a negative impact on the river ecosystem (Friedl and Wüest, 2002; Ye et al., 2007; Martínez et al., 2013). It contributes to changes in environmental conditions, which in turn affect biotic communities in the stream (Ward and Stanford, 1983; Myers et al., 2000; Ogbeibu and Oribhabor, 2002; Jorcin et al., 2009; Phillips et al., 2015).

Impoundment of a river results in decreasing the water velocity and prolonging water residence time upstream of the

\footnotetext{
*Corresponding author: jzbikow@umk.pl
}

dam (Shao et al., 2008; Poff and Zimmerman, 2010; Zhang et al., 2010). Taking into account the water residence time, we can distinguish two types of dam reservoirs: rheolimnic (with water residence time shorter than 36 days) and limnetic (with water residence time longer than 36 days) (Starmach, 1958). The hydrological regime of a dam reservoir significantly influences its abiotic environment and, in consequence, the macrozoobenthos structure (Fleituch, 2000; Zhang et al., 2010).

A discontinuity of water flow rate and abiotic features results in creating three zones in the reservoir: riverine zone, characterized by high water flow and high levels of suspended solids, transition zone with decreasing flow velocity and intense sedimentation of silt and clay particles, and lacustrine zone characterized by small water dynamics, and lower concentration of suspended abiogenic particles resulting in higher water transparency (Kimmel et al., 1990). Depending on inflow characteristics and flushing rates all three zones may not always be distinguishable within a particular impoundment or their proportions can be different. For example, in reservoirs with a very short water residence time, conditions characteristic of the riverine zone may persist throughout most of the reservoir (Thornton, 1990). In contrast, in reservoirs with a long water residence time both the riverine and transition zones 


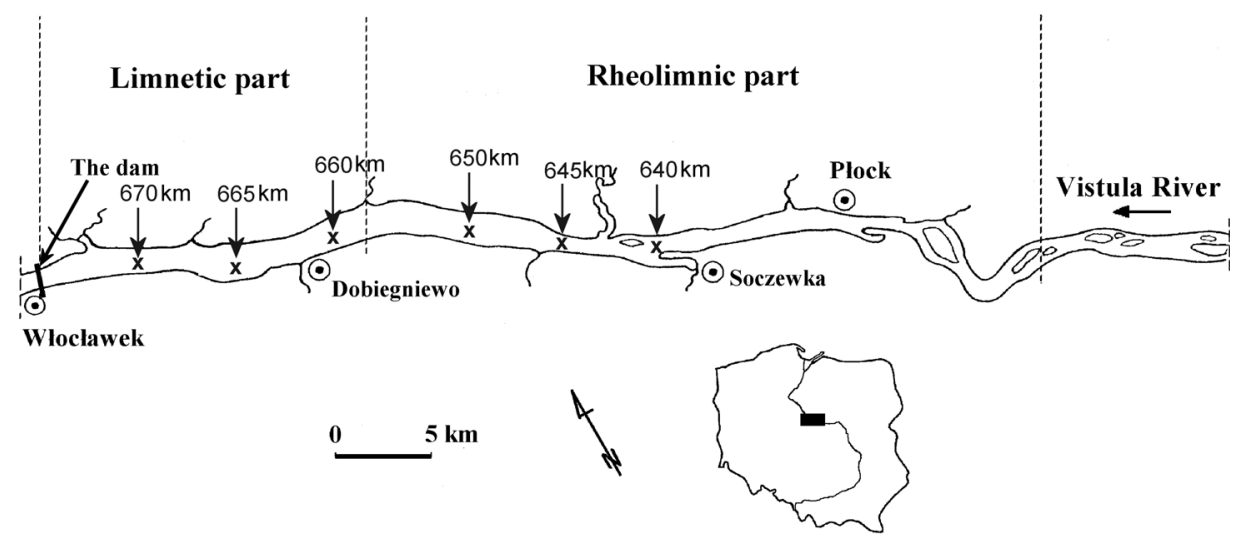

Fig. 1. Location of the sampling sites in the Włocławek dam reservoir.

may be compressed into a small, uplake portion of the basin (Thornton et al., 1981). Anyway, from its headwater to the dam, a fluvial system transforms into a more lacustrine one. Consequently, along its longitudinal gradient, changes in water quality occur (for e.g., alterations of thermal and oxygen conditions). Moreover, the prevalence of deposition over transport processes contributes to the accumulation of sediments, organic matter and nutrients on the bottom of the reservoir (Friedl and Wüest, 2002; dos Santos et al., 2016). The intensity of these environmental changes is different in particular zones of the dam reservoir, but all of these modifications may strongly affect the structure of macrozoobenthos along the reservoir (Gore et al., 2001; Callisto et al., 2005; McEwen and Butler, 2010; Behrend et al., 2012; Gillespie et al., 2014).

Bottom fauna play an extremely important role in the functioning of aquatic ecosystems. This is due to its influence on the processes occurring in the surface layer of bottom sediments, for example the exchange of substances between the sediments and water. In turn, these processes contribute to changes in productivity in water bodies. Macrozoobenthos is also an important link in every food chain (dos Santos et al., 2016). Moreover, these organisms can very well reflect longtime trends of changes in the ecosystem, due to their weak motility (Moreno and Callisto, 2006). Identifying the spatial distribution of benthic communities allows the determination of their responses to environmental gradients and variations in flow regimes (Wills et al., 2006; Angradi et al., 2009; Pelletier et al., 2010).

The most important factors influencing benthic macroinvertebrates in dam reservoirs include depth-related variables, such as consequences of thermal stratification, for example oxygen concentration at the bottom (Moretto et al., 2003). Moreover, benthic fauna are affected by water transparency (Zhang et al., 2010), substrate type (Moretto et al., 2003), as well as organic matter content in sediments (Jorcin et al., 2009). However, investigations on the relations between environmental variables and bottom fauna in dam reservoirs are rare. Most of existing research concerning macrozoobenthos deal with natural water bodies, while studies in artificial reservoirs are much less common (Han, 2010).

Most of the studies concerning the bottom fauna in dam reservoirs were conducted in typical rheolimnic or limnetic reservoirs. However, the Włocławek Dam Reservoir (WDR) is a specific, strongly rheolimnic reservoir, in which water flow rate is much higher (only several-day long time of water retention) than in most others reservoirs (Giziński et al., 1989). Thus, it is not certain if in such a rheolimnic reservoir as the WDR changes in macrozoobenthos structure along the reservoir longitudinal profile are similar as those in typical reservoirs.

Thus, the aim of our study was to compare the macrozoobenthos structure and water and organic matter content of bottom sediments of two hydrologically different zones of a strongly fluvial dam reservoir, using on the example of the WDR.

We hypothesized that the number of macrozoobenthos taxa and diversity should be higher in the URP than in the LLP but the differences in macrozoobenthos structure between the two zones should not be as pronounced as in other reservoirs.

\section{Study area}

The Włocławek Dam Reservoir (WDR) is situated in the lower course of the Vistula river, between the 618th and the 675 th kilometre of the water-course (Fig. 1). The reservoir was created in 1970, and its main function has been the energy generation and water retention. It is the largest Polish reservoir with respect to surface area and the second largest considering volume. The basic morphometric parameters of the WDR, according to Grzes (1983), are as follows: surface area $75 \mathrm{~km}^{2}$, total volume $400 \mathrm{mln} \cdot \mathrm{m}^{3}$, usable volume $55 \mathrm{mln} \cdot \mathrm{m}^{3}$, mean width $1,210 \mathrm{~m}$ (range 500-2,500 m), mean depth $5 \mathrm{~m}$ (maximum $15 \mathrm{~m}$ ), mean water flow $900 \mathrm{~m}^{3} \cdot \mathrm{s}^{-1}$.

As mentioned earlier, a particular feature of the WDR is its very short water residence time (ca. 4-7 days). Thus, the reservoir is strongly rheolimnic, with a very elongated, channel-like shape. The WDR is a highly eutrophic water body (Żytkowicz et al., 1990; Kentzer et al., 1999) but its hydrodynamic conditions, such as the high water flow rate and intensive wind mixing resulting from the large area and suitable localisation, reduce many negative consequences of the high productivity. For example, the lack of a strong, longlasting thermal stratification results in relatively good oxygen conditions at the bottom zone of the reservoir (Żbikowski, unpublished data).

Despite the overall rheolimnic character of the WDR two distinctly different zones may be distinguished (Fig. 1): (1) the 
upper rheolimnic part (URP), from the 657 th $\mathrm{km}$ of the river course upstream, with the water flow rate over $1.0 \mathrm{~m} \cdot \mathrm{s}^{-1}$ and (2) the lower limnetic part (LLP), spreading from the dam up to the $657 \mathrm{th} \mathrm{km}$ of the river course, with the water flow rate ranging from $0.1 \mathrm{~m} \cdot \mathrm{s}^{-1}$ (at the inflow of $993 \mathrm{~m}^{3} \cdot \mathrm{s}^{-1}$ ) to $0.4 \mathrm{~m} \cdot \mathrm{s}^{-1}$ (at the inflow of $3680 \mathrm{~m}^{3} \cdot \mathrm{s}^{-1}$ ) (Grzes, 1983).

A very important factor, influencing the hydrological conditions in the reservoir, is its small usable volume $(14 \%$ of the total volume), resulting in low fluctuations of the water level - usually below $0.5 \mathrm{~m}$ (Żbikowski et al., 2007).

\section{Methods}

The samples were collected during the summer and autumn of 1997 and spring of 1998, at six sampling sites located along the former river Vistula bed. Three of them were localized in the URP of the reservoir and three other in their LLP. (Fig. 1). The sampling sites in the URP were located at 640th, 645th and $650 \mathrm{th} \mathrm{km}$ of the river Vistula course. The depths of these sites were as follows: $4.0 \mathrm{~m}, 4.5 \mathrm{~m}, 5.2 \mathrm{~m}$. In the LLP, the sampling sites were located at $660 \mathrm{th}, 665$ th and 670 th $\mathrm{km}$ of the rivercourse and their depths were $10.0 \mathrm{~m}, 11.0 \mathrm{~m}$ and $11.2 \mathrm{~m}$ respectively.

\subsection{Bottom fauna}

The macrozoobenthos samples were taken using an Ekman-Birge grab (catching area: $225 \mathrm{~cm}^{2}$ ). At each sampling site, we took 2-4 replicate samples depending on the bottom fauna abundance. The samples were rinsed using a $0.5 \mathrm{~mm}$ sieve and preserved in $4 \%$ formaldehyde. To assess the fresh biomass of the macrozoobenthos, preserved animals were dried on blotting paper and weighed to the nearest $0.0001 \mathrm{~g}$ with an analytical scales PRL T A13 (Poland). Mollusc biomass included their shells. The Chironomidae larvae were determined on the basis of Wiederholm (1983). In the case of Oligochaeta, a key by Kasprzak (1981) was used, while taxonomic identification of Mollusca was carried out using keys by Piechocki (1979) and Piechocki and DyduchFalniowska (1993).

\subsection{Abiotic parameters}

Simultaneously with the collection of macrozoobenthos samples, some abiotic parameters were determined. Water transparency was measured by means of a Secchi disc. The bottom sediments (their $0-5 \mathrm{~cm}$ surface layer) were taken by means of a Kajak core sampler with a catching area of $10 \mathrm{~cm}^{2}$. Water and organic matter content in the sediments were measured by the methods described by Hakanson and Jansson (1983). The latter parameter was presented as the percentage of the sediment dry mass.

\subsection{Statistical analysis}

The differences between the two zones in abiotic and zoobenthic parameters were analysed using two-way ANOVAs with reservoir zone and season as factors. In the Results section, we only report significant main effects of
Table 1. Measured abiotic parameters (average values) in the rheolimnic and limnetic zones of the Włocławek Dam Reservoir.

\begin{tabular}{lll}
\hline Parameters & Rheolimnic zone & Limnetic zone \\
\hline Depth (m) & 4.6 & 10.7 \\
Secchi depth ${ }^{*}$ & 0.8 & 1.0 \\
Bottom sediments & & \\
Water content (\%) $^{*}$ & 60.0 & 78.7 \\
Organic matter content (\%) & 5.8 & 11.4 \\
\hline
\end{tabular}

${ }^{*}$ Statistically significant difference.

reservoir zone as we were interested in determining permanent differences between the zones, independent of seasonal fluctuations. The data were log-transformed to meet the normality and homoscedasticity assumptions. The analyses were conducted in IBM SPSS Statistics 24.0.

\section{Results}

\subsection{Abiotic parameters}

Water transparency was higher in the LLP (Secchi disc depth: $1.0 \mathrm{~m})$ than in the URP $(0.8 \mathrm{~m})$ (Tab. 1$)$. The difference between these two zones was small, but statistically significant (Suppl. Tab. 1). Both water and organic matter content of bottom sediments, were also significantly higher in the LLP of the WDR $(78.7 \% ; 11.4 \%$ respectively) than in the URP $(60.0 \% ; 5.8 \%)$.

\subsection{Bottom fauna}

During the course of the study 25 macrozoobenthos taxa were found (Tab. 2). Both the number of taxa and diversity of the bottom fauna (average per one sample), the latter based on Shannon index, were significantly higher in the URP of the WDR $(22 ; 2.49$ respectively) than in the $\operatorname{LLP}(16 ; 1.92)$ (Suppl. Tab. 2).

The dominance structure of benthic fauna, based on their density, was similar in both zones (Fig. 2). Oligochaetes definitely dominated. Their share in the URP was $70 \%$ while in the LLP $76 \%$ of the total macrozoobenthos density. An important element of the benthic fauna was also constituted by chironomid larvae. In both zones, these two groups of animals together accounted for over $90 \%$ of the total macrozoobenthos density. Mollusca occurred in relatively large density only in the URP of the WDR (almost 10\%), while their share in the LLP was very small. The presence of Hirudinea, at small density, was found only in the upper part of the reservoir, in turn, Nematoda occurred only in its lower part.

In terms of biomass, as opposed to the density, the large difference in the dominance structure of macrozoobenthos between two zones was found. In the URP of the reservoir, Mollusca dominated (almost $80 \%$ of the total biomass of the benthic fauna) (Fig. 3). However, it should be noted, that these organisms were weighed along with their shell, which contributed to the high values of the biomass of this group of animals. In the LLP, chironomid larvae prevailed in terms of biomass (64\%). The oligochaetes were also an important group 
Table 2. Number of taxa and diversity (both average per one sample), as well as average density (ind. $\mathrm{m}^{-2}$ ) of the macrozoobenthos in the rheolimnic and limnetic zone of the Włocławek Dam Reservoir.

\begin{tabular}{|c|c|c|}
\hline Macrozoobenthos & $\begin{array}{l}\text { Rheolimnic } \\
\text { zone }\end{array}$ & $\begin{array}{l}\text { Limnetic } \\
\text { zone }\end{array}$ \\
\hline \multicolumn{3}{|l|}{ OLIGOCHAETA } \\
\hline Number of taxa - total & 9 & 8 \\
\hline Number of taxa - per one sample ${ }^{*}$ & 7 & 6 \\
\hline Shannon index - per one sample & 1.95 & 1.72 \\
\hline Limnodrilus hoffmeisteri & 22964 & 33624 \\
\hline Limnodrilus claparedeanus & 12915 & 21525 \\
\hline Potamothrix hammoniensis * & 2165 & 7732 \\
\hline Potamothrix bavaricus & 4066 & 3008 \\
\hline Tubifex tubifex ${ }^{*}$ & 6283 & 1034 \\
\hline Limnodrilus profundicola & 1576 & 2897 \\
\hline Potamothrix moldaviensis ${ }^{*}$ & 1154 & 0 \\
\hline Limnodrilus udekemianus ${ }^{*}$ & 528 & 14 \\
\hline Dero $s p$ & 0 & 116 \\
\hline Psammoryctides sp. & 96 & 0 \\
\hline OLIGOCHAETA - total & 51747 & 69949 \\
\hline \multicolumn{3}{|l|}{ CHIRONOMIDAE } \\
\hline Number of taxa - total & 4 & 5 \\
\hline Number of taxa - per one sample ${ }^{*}$ & 3 & 2 \\
\hline Shannon index - per one sample & 0.62 & 0.29 \\
\hline Chironomus sp. & 13661 & 19886 \\
\hline Glyptotendipes sp. ${ }^{*}$ & 1558 & 20 \\
\hline Procladius sp. & 436 & 248 \\
\hline Cryptochironomus sp. ${ }^{*}$ & 358 & 2 \\
\hline Polypedylum nubeculosum & 0 & 6 \\
\hline Chironomidae pupae & 0 & 33 \\
\hline CHIRONOMIDAE - total & 16013 & 20195 \\
\hline \multicolumn{3}{|l|}{ MOLLUSCA } \\
\hline Number of taxa - total & 8 & 2 \\
\hline Number of taxa - per one sample ${ }^{*}$ & 4 & 1 \\
\hline Shannon index - per one sample & 0.81 & 0.17 \\
\hline Sphaerium $s p$ & 3698 & 763 \\
\hline Pisidium sp. & 1296 & 14 \\
\hline Valvata $^{*}$ & 55 & 0 \\
\hline Bithynia tentaculata ${ }^{*}$ & 28 & 0 \\
\hline Viviparus viviparus ${ }^{*}$ & 30 & 0 \\
\hline Dreissena polymorpha ${ }^{*}$ & 19 & 0 \\
\hline Unio sp. ${ }^{*^{\prime}}$ & 17 & 0 \\
\hline Radix auricularia & 8 & 0 \\
\hline MOLLUSCA - total & 5124 & 776 \\
\hline HIRUDINEA* $^{*}$ & 602 & 0 \\
\hline NEMATODA ${ }^{*}$ & 0 & 69 \\
\hline \multicolumn{3}{|l|}{ ZOOBENTHOS - total } \\
\hline Number of taxa - total & 22 & 16 \\
\hline Number of taxa - per one sample ${ }^{*}$ & 16 & 10 \\
\hline Shannon index - per one sample ${ }^{*}$ & 2.49 & 1.92 \\
\hline ZOOBENTHOS & 73486 & 90990 \\
\hline
\end{tabular}

* Statistically significant difference.

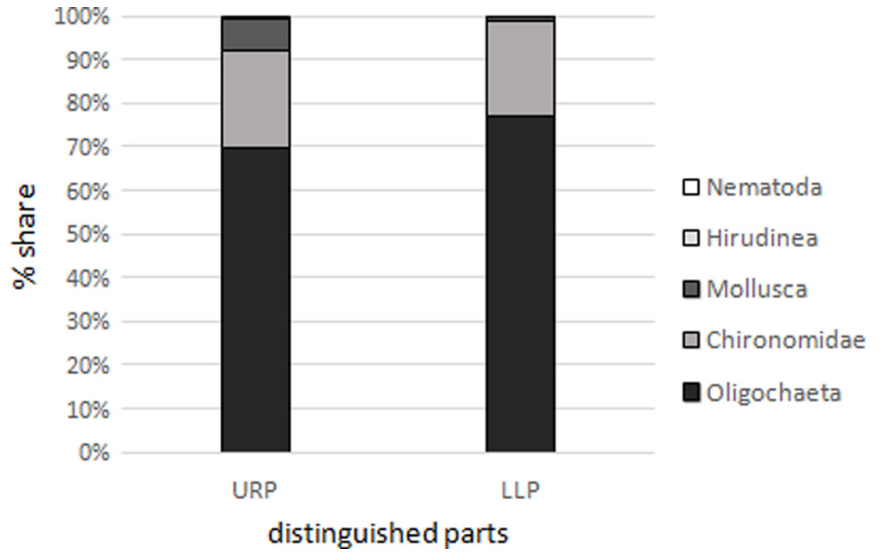

Fig. 2. Percentage share of the particular taxonomic groups in the total density of macrozoobenthos in the distinguished parts in the Włocławek Dam Reservoir. The results were based on three sampling occasions. URP - upper rheolimnic part, LLP - lower limnetic part.

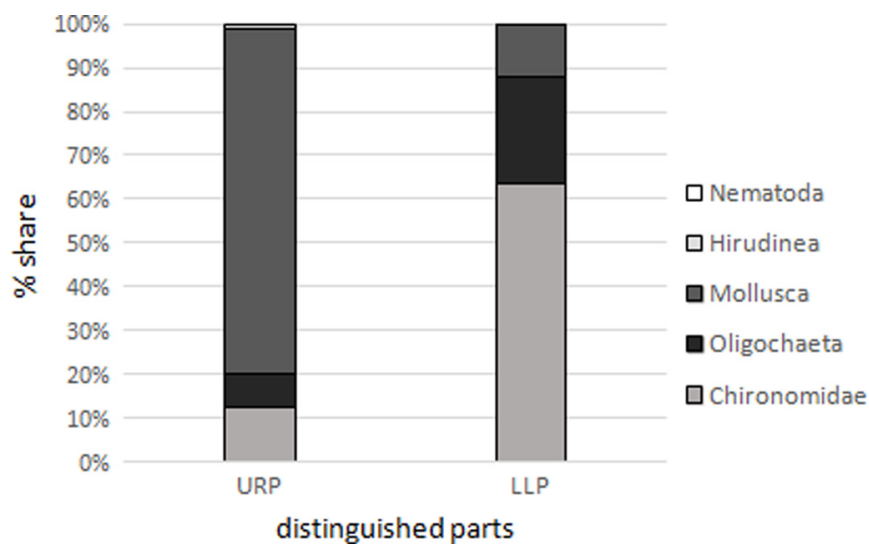

Fig. 3. Percentage share of the particular taxonomic groups in the total biomass of macrozoobenthos in the distinguished parts in the Włocławek Dam Reservoir. The results were based on three sampling occasions. URP - upper rheolimnic part, LLP - lower limnetic part.

of the benthic fauna in the latter zone. They accounted for about $24 \%$ of the total macrozoobenthos biomass.

The total density of benthic fauna was similar in both compared parts of the WDR. It was slightly higher in the LLP (almost 91 thous. ind. $\mathrm{m}^{-2}$ ) than in the URP (nearly 74 thous. ind. $\mathrm{m}^{-2}$ ), but this difference was not statistically significant (Tab. 2). However, total macrozoobenthos biomass was significantly higher in the URP of the reservoir $(2,314$ $\left.\mathrm{g} \cdot \mathrm{m}^{-2}\right)$ than in the LLP $\left(336 \mathrm{~g} \cdot \mathrm{m}^{-2}\right)$ (Tab. 3) (Suppl. Tab. 3). We also calculated the biomass of the benthic fauna without Mollusca. Based on this biomass, there has also been a significant difference between the URP $\left(466 \mathrm{~g} \cdot \mathrm{m}^{-2}\right)$ and the LLP $\left(295 \mathrm{~g} \cdot \mathrm{m}^{-2}\right)$ of the WDR.

\subsection{Oligochaeta}

The total number of Oligochaeta taxa was comparable in the URP (9) and in the LLP (8) (Tab. 2). Shannon index was slightly, but significantly higher in the URP of the reservoir (1.95) than in the LLP (1.72). 
Table 3. The average biomass $\left(\mathrm{g} \cdot \mathrm{m}^{-2}\right)$ of the macrozoobenthos in the rheolimnic and limnetic zone of the Włocławek Dam Reservoir.

\begin{tabular}{|c|c|c|}
\hline Macrozoobenthos & $\begin{array}{l}\text { Rheolimnic } \\
\text { zone }\end{array}$ & $\begin{array}{l}\text { Limnetic } \\
\text { zone }\end{array}$ \\
\hline Unio sp. ${ }^{*}$ & 1418.05 & 0.00 \\
\hline Sphaerium sp. ${ }^{*}$ & 347.71 & 40.51 \\
\hline Viviparus viviparus ${ }^{*}$ & 63.34 & 0.00 \\
\hline Pisidium sp. & 10.88 & 0.13 \\
\hline Bithynia tentaculata ${ }^{*}$ & 3.94 & 0.00 \\
\hline Dreissena polymorpha ${ }^{*}$ & 2.80 & 0.00 \\
\hline Valvata piscinalis ${ }^{*}$ & 1.35 & 0.00 \\
\hline Radix auricularia & 0.73 & 0.00 \\
\hline MOLLUSCA - total ${ }^{*}$ & 1848.79 & 40.64 \\
\hline OLIGOCHAETA $^{*}$ & 168.72 & 81.34 \\
\hline CHIRONOMIDAE & 266.43 & 213.59 \\
\hline HIRUDINEA $^{*}$ & 30.48 & 0.00 \\
\hline NEMATODA $*$ & 0.00 & 0.13 \\
\hline ZOOBENTHOS - total ${ }^{*}$ & 2314.42 & 335.72 \\
\hline ZOOBENTHOS - without Mollusa ${ }^{*}$ & 465.63 & 295.07 \\
\hline
\end{tabular}

${ }^{*}$ The difference statistically significant.

Potamothrix moldaviensis was the only species that occurred exclusively in the URP of the reservoir (Tab. 2). In this zone, significantly higher densities of Tubifex tubifex and Limnodrilus udekemianus were also found. In contrast, Potamothrix hammoniensis was much more numerous in the LLP of the WDR. The differences in the densities of the remaining Oligochaeta taxa between the two zones were not statistically significant (Suppl. Tab. 2).

The total oligochaete density was higher in the URP (almost 70 thous. ind. $\mathrm{m}^{-2}$ ) than in the LLP (nearly 52 thous. ind $\mathrm{m}^{-2}$ ) but the difference was not statistically significant. In turn, the biomass of these animals was twice as high (a statistically significant difference) in the URP $\left(169 \mathrm{~g} \cdot \mathrm{m}^{-2}\right)$ than in the LLP $\left(81 \mathrm{~g} \cdot \mathrm{m}^{-2}\right)$.

\subsection{Chironomidae}

As in the case of oligochaetes, the total number of chironomid taxa was similar in the URP (4) and in the LLP (5) (Tab. 2). However, in the former, the diversity of this group was substantially higher (0.62) than in the latter (0.29).

Glyptotendipes sp. and Cryptochironomus sp. larvae reached significantly higher densities in the URP while the densities of other chironomid taxa (Chironomus sp., Procladius sp., Polypedylum nubeculosum) were comparable in both zones of the reservoir.

The total density of chironomid larvae was similar in both rheolimnic and limnetic zones (16 and 20 thous. ind. $\mathrm{m}^{-2}$ respectively). Similarly to the density, there was no significant difference in the biomass of this group between the upper $\left(266 \mathrm{~g} \cdot \mathrm{m}^{-2}\right)$ and the lower part $\left(214 \mathrm{~g} \cdot \mathrm{m}^{-2}\right)$ of the WDR (Tab. 3).

\subsection{Mollusca}

Both the number of molluscan taxa (average per one sample) and their diversity were significantly higher in the URP of the WDR $(4 ; 0.81$ respectively) than in the LLP
$(1 ; 0.17)$ (Tab. 2). It is worth noting that the presence of snails was found only in the URP of the reservoir. There were big differences in the densities of Sphaerium sp., and Pisidium sp. (Sphaeriidae) between the two zones, but they were not significant in statistical terms (Suppl. Tab. 2).

The total density of Mollusca was significantly higher in the URP $\left(5,124\right.$ ind. $\left.\mathrm{m}^{-2}\right)$ than in the LLP (776 ind. $\left.\mathrm{m}^{-2}\right)$. In the former, the biomass of these animals (Tab. 3) was as many as 45 times higher than in the latter (1849 and $41 \mathrm{~g} \cdot \mathrm{m}^{-2}$ respectively).

In summary, the compared zones of the WDR differed significantly from each other in terms of abiotic parameters under study and the benthic fauna structure. In the URP, both water transparency and water and organic matter content in bottom sediments were lower. With regard to the benthic fauna, the biggest differences were related to the Mollusca, whose number of taxa, diversity and abundance were much higher in the URP of the WDR. Also, the number of taxa, diversity and total biomass of macrozoobenthos were higher in the URP.

\section{Discussion}

The results of our research confirmed the previously observed general rules concerning the changes of abiotic parameters and macrozoobenthos structure along the reservoir (McEwen and Butler, 2010; Gillespie et al., 2014), however, due to the very short water residence time, the differences in the parameters under study between the URP and the LLP of the WDR were smaller than in other reservoirs.

Water transparency as well as organic matter and water content in the bottom sediments were higher in the LLP than in the URP in the WDR. Similar results (differences between the upper and lower part of a reservoir) were also found in many other reservoirs in the world (Grzybowska, 1965; Olszewski and Mówińska, 1985; Di Giovanni et al., 1996; Moretto et al., 2003; Jorcin et al., 2009; Liu et al., 2011). The reason for these differences was probably the different depth of the zones and the change in the hydrological regime resulting in the higher sedimentation rate of the suspended particles in the lower zone of the reservoir (Dusoge et al., 1985; Zhang et al., 2010), which in turn changed the type of bottom sediments from sandy-muddy to muddy. As mentioned earlier, the differences in measured parameters between the zones in the WDR were smaller than in other above cited reservoirs, probably due to specificity of the WDR.

The benthic fauna of both analyzed zones of the WDR was represented by 25 taxa. The number of macrozoobenthos taxa was comparable to that recorded in another strongly rheolimnic reservoir (Dusoge et al., 1985; Di Giovanni et al., 1996; Prus and Wisniewolski, 2005; Liu et al., 2011). In turn, in most of the studied reservoirs a lower number of total macrozoobenthos taxa was reported (Krzyżanek, 1971; Giziński and Wolnomiejski, 1982; Popp and Hoagland, 1995; Corbi and Trivinho-Strixino, 2002; Moretto et al., 2003; Puczyńska, 2004; Pamplin et al., 2006; Prus, 2006). According to Fleituch (2000), once a dam has been built on a river, there is a decline of the diversity of the bottom fauna due to the disappearance of rheophilous species. However, larger changes take place in limnetic reservoirs than in rheolimnic 
ones, which may explain the higher number of macrozoobenthos taxa in the WDR compared to many other reservoirs.

Both the number of taxa and the diversity of macrozoobenthos and its particular groups were generally higher in the URP of the WDR than in its LLP. Similar results were also found in other dam reservoirs (Dusoge et al., 1990; Prat et al., 1992; Petridis and Sinis, 1993; Di Giovanni et al., 1996; Moretto et al., 2003; Jorcin et al., 2009; Liu et al., 2011). According to the above-cited authors, the explanation of the observed differences is the increase in depth, the decrease in oxygen concentration near the bottom and the accumulation of the muddy sediment layer at the bottom along the dam reservoir. These are typical changes observed in many reservoirs (Ogbeibu and Oribhabor, 2002; Jorcin et al., 2009).

The decrease in the water oxygen concentration along the WDR was also reported (Giziński et al., 1989; Żytkowicz et al., 1990; Kentzer et al., 1999). In its LLP in summer the water oxygen concentration near the bottom is generally around $3 \mathrm{mg} \cdot \mathrm{dm}^{-1}$ (Żbikowski, unpubl. data). Low water oxygenation in that zone is a consequence of the increase in depth and organic matter content in the sediments and the decrease in water circulation, which is likely to result in qualitative depletion of the bottom fauna. However, it should be noted that in the reservoir under study the differences in the number of total macrozoobenthos taxa between the compared zones were lower than in the corresponding zones in other reservoirs (Petridis and Sinis, 1993; Di Giovanni et al., 1996; Smiljkov et al., 2008; Liu et al., 2011). Probably due to the considerable specificity of the WDR, resulting from its very short water residence time, the number of taxa and diversity of benthic fauna in its LLP were still relatively high compared to other reservoirs.

In terms of the number of taxa and diversity, the biggest changes concerned the molluscs. There were 8 taxa in the rheolimnic zone, including Gastropoda and Bivalvia, while in the limnetic zone only 2 taxa, belonging exclusively to Bivalvia, were found. There was generally a higher number of Mollusca taxa in the WDR than in many other reservoirs (Corbi and Trivinho-Strixino, 2002; Pamplin et al., 2006; Jorcin et al., 2009; Liu et al., 2011), which again emphasizes its uniqueness. In the Xin'anjiang Reservoir in China (Liu et al., 2011) and in the Americo Reservoir in Brasil (Corbi and Trivinho-Strixino, 2002) Mollusca occurred only in their rheolimnic zones while in the Montedoglio Reservoir in Italy (Di Giovanni et al., 1996) and in the Siemianówka Reservoir in Poland (Prus, 2006), no such benthic organisms were found at all.

Molluscan fauna is strongly influenced by depth, substrate type and, above all, the water flow rate in the reservoir (Dusoge et al., 1990; Żbikowski et al., 2007). Studies carried out in the near shore zone of the WDR (Żbikowski et al., 2007) showed much greater differences in the molluscan structure between sites with different water flow rates and a similar type of bottom sediments than between sites of the same water flow rate but with different sediment types. Significant decrease in the number of taxa and diversity of Mollusca along the reservoir as well as the lack of snails in its limnetic part could also be due to the increase in sediment water content resulting in the collapse of larger Gastropoda species into the sediments.
In terms of density, Sphaeriidae clams dominated among molluscs in the WDR. Their clear dominance in other lowland Polish reservoirs (Krzyżanek, 1976; Jurkiewicz-Karnkowska, 1989) was also observed. According to Beisel et al. (2000) Sphaerium sp. is abundant in habitats with moderate water flow and sandy-muddy sediments, which is probably the main cause of its higher densities in the rheolimnic zone. These mussels are indicators of low water quality (Kudelska and Soszka, 1996); thus, their dominance in the molluscan fauna confirms the high trophy level of the WDR.

The diversity of chironomid larvae was higher in the URP than in the LLP. A similar situation was also reported in other reservoirs (Grzybowska, 1965; Krzyżanek, 1971; Petridis and Sinis, 1993; Moretto et al., 2003). There were no significant differences between the zones in the densities of the dominant taxon Chironomus sp. and Procladius sp., the latter also occurring in relatively large densities. Both taxa dominated also in the Montedoglio Reservoir, where they also did not show significant differences in densities between the upper and lower part of the reservoir (Di Giovanni et al., 1996). Chironomus sp. also dominated in the Zegrzyński Reservoir (Prus, 2009) and was one of the dominant taxa in the Ribeirao das Anhumas Reservoir in Brazil, where its densities in different zones were comparable (Corbi and Trivinho-Strixino, 2002). On the other hand, a significantly higher density of Chironomus sp. in the rheolimnic part than in the limnetic one in the Pawnee Reservoir was found (Popp and Hoagland, 1995). Chironomus sp. and Procladius sp. are taxa typical for eutrophic reservoirs (Dumnicka et al., 1986; Prat et al., 1992; Fleituch, 2000), very resistant to unfavourable environmental conditions, especially low oxygen concentration (Armitage et al., 1995; Nyman et al., 2005). They are also extremely plastic, easily adaptable to different conditions (Baker and McLachlan, 1979; Sokolova, 1983; Armitage et al., 1995), including their way of obtaining food (Johnson et al., 1989; Berg, 1995; Kajak and Prus, 2001). Therefore, the lack of difference in the density of these taxa between the compared zones of the WDR is not surprising.

Taxa exhibiting significantly higher densities in the URP of the WDR were Glyptotendipes sp. and Cryptochironomus sp. larvae. Ali et al. (2002) reported that the abundance of Glyptotendipes sp. inversely correlated with the depth of the reservoir and the organic matter content in the sediments. Dusoge (1989) stated that Glyptotendipes sp. was more numerous in an environment of rapid water flow. Cryptochironomus sp. larvae were also more abundant in the rheolimnic zone in the Montedoglio Reservoir (Di Giovanni et al., 1996) and in the Porto Primavera Reservoir (Jorcin et al., 2009) while in the Xin'anjiang Reservoir it only appeared in its rheolimnic part (Liu et al., 2011). According to Kuklińska (1992) both taxa inhabit mainly littoral or sublittoral zones of lakes, which means that they prefer sandy or sandy-muddy sediments. Taking into account the above-mentioned information it seems obvious why Glyptotendipes sp. and Cryptochironomus sp. larvae were more numerous in the URP of the WDR.

Similarly to Chironomidae larvae, Oligochaeta diversity was also higher in the URP than in the LLP of the WDR. In this group, we can also distinguish taxa that do not show the difference in the density between the analyzed zones, including dominant taxa, as well as taxa occurring in greater numbers in the URP and taxa reaching higher densities in the LLP. Among 
oligochaetes, the genus Limnodrilus sp., especially Limnodrilus hoffmeisteri definitely dominated. The main reason for such a numerous occurrence of this taxon in the URP, and above all in the LLP, was probably its resistance to unfavourable oxygen conditions (Gong and Xie, 2001; Liu and Wang, 2007), and the likely significant contribution of allochthonous organic matter in sediments, which is the preferred source of food for this taxon (Kasprzak, 1981). $L$. hoffmeisteri abundantly occurs on the muddy-sandy bottom (Grigelis, 1990), which can also explain its dominance in the WDR. The dominance of this species was also found in other dam reservoirs (Dumnicka, 1993; Pamplin et al., 2006; Smiljkov et al., 2008; Liu et al., 2011).

Potamothrix moldaviensis (Oligochaeta) was found only in the URP. Its presence confirms the significant contribution of sand in the sediments of this zone, as it belongs to psammophilic taxa (Milbrink and Timm, 2001), occurring mainly in the littoral of lakes or in rivers.

In the URP, the higher density of Tubifex tubifex was found. Similar pattern was observed in the Xin'anjiang Reservoir (Liu et al., 2011). T. tubifex is resistant to unfavourable environmental conditions, but due to its sensitivity to interspecific competition (Brinkhurst, 1969), along with the deterioration of environmental conditions, is displaced by Potamothrix hammoniensis (Timm, 1970).

Potamothrix hammoniensis, a species preferring standing waters, tolerating prolonged oxygen deficits (Berg et al., 1962; Risnoveanu and Vadineanu, 2002) was definitely more numerous in the LLP of the WDR. It thrives in sediments dominated by autochthonous organic matter (Kasprzak, 1981). So, the higher density of $P$. hammoniensis in the LLP of the WDR is not surprising, since the share of organic matter of autochthonous origin is likely to be greater in this zone.

Generally the total macrozoobenthos density in the WDR was similar to that in the Zegrzyński Reservoir (Dusoge, 1989) but much higher than in many other Polish reservoirs (Krzyżanek, 1977; Giziński and Wolnomiejski, 1982; Dumnicka et al., 1986; Płużański et al., 1990; Fleituch, 2000; Puczyńska, 2004) and Tavropos in Greece (Petridis and Sinis, 1993). Thus, run-off reservoirs, such as the WDR and the Zegrzyński, are characterized by many times higher density of the bottom fauna than those observed in the limnic reservoirs, which confirms the significant influence of the water flow rate in the dam reservoir on the macrozoobenthos structure (Giziński et al., 1989; Dusoge et al., 1990).

There was no significant difference in the total macrozoobenthos density between the URP and the LLP of the WDR. A similar situation was also found in the Zegrzyński Reservoir (Dusoge, 1989), with equally very short water retention time. No significant difference in the density of the macrozoobenthos between upper and lower part of the WDR may result from the fact that in both zones taxa resistant to unfavourable environmental conditions dominated. The large amount of valuable food reaching the bottom due to lower water flow and higher sedimentation rate as well as the lack of sharp, long-lasting oxygen deficiencies in the limnetic zone have probably contributed to the high abundance of benthic fauna also in the LLP of the WDR. In turn, in the limnic reservoirs much lower densities of bottom fauna in their lower part were found (Krzyżanek, 1977; Pamplin et al., 2006; Prus, 2006; Liu et al., 2011). It can be assumed that in the limnic reservoirs, due to the low water flow rate especially in their lower part, very likely frequent oxygen deficiencies prevented the achievement of high density even by tolerant macrozoobenthos taxa.

In the URP of the reservoir, higher densities of molluscs were observed, whereas the densities of chironomid larvae and oligochaetes were slightly higher in the limnetic zone, but these differences were not statistically significant. These results are consistent with expectations, as the higher density of Mollusca in the upper part in the Zegrzyński Reservoir (Dusoge et al., 1990) was also found. In addition, the increase in Oligochaeta densities along a reservoir in many other dam reservoirs were also recorded (Grzybowska, 1965; Fleituch, 2000).

Generally, in both zones oligochaetes distinctly dominated in terms of density. This was probably related to the increase in the mud layer at the bottom of the reservoir, which contributes to improve nutritional conditions for this group (Rieradevall, 1991; Beisel et al., 2000; Ciutat et al., 2006). The chironomid larvae were also an important element of the bottom fauna. In both zones, these two groups of animals accounted for over $90 \%$ of the total macrozoobenthos density. The quantitative proportions between these two groups in both zones were comparable, although slightly higher share of Oligochaeta in the LLP was found. These two groups include extremely tolerant benthic organisms, occurring in different environments (Rosenberg and Resh, 1993).

The biomass of the bottom fauna was substantially higher in the URP than in the LLP. Also, the biomass of so-called "soft" zoobenthos (excluding mollusca), was significantly higher in the URP of the reservoir than in the LLP. In most of the previously cited papers, higher biomasses of bottom fauna in the zones of faster water flow were also recorded. Similarly to the density, the bottom fauna biomass in the WDR was also high compared to most dam reservoirs, where it was usually approximately several $\mathrm{g} \cdot \mathrm{m}^{-2}$ (Kajak, 1962; Kajak, 1989; Prus, 2006). The total macrozoobenthos biomass found in the WDR was similar to that recorded only in the Zegrzyński Reservoir (Dusoge et al., 1985; Dusoge et al., 1990; Kajak and Prus, 2003; Prus and Wisniewolski, 2005). In the URP of the WDR molluscs dominated in this respect, which was largely due to the fact that individuals belonging to this group were weighed together with shells, while in the LLP the chironomid larvae prevailed. The domination of molluscan fauna in respect of the biomass was also found in the Zegrzyński Reservoir (Dusoge et al., 1990). The very high macrozoobenthos biomass recorded in the WDR creates exceptionally favourable nutritional conditions for benthic fish living therein, which confirms the high rate of bream growth in this reservoir (Kakareko, 2000).

\section{Conclusions}

The Włocławek Dam Reservoir, due to its extremely short water residence time, is not a typical dam reservoir. Nevertheless, as in many other dam reservoirs, the differences in the values of the measured abiotic parameters and the number of taxa, diversity, and the biomass of bottom fauna between the distinguished zones were significant. However, there were no significant differences in the total 
macrozoobenthos density between the URP and the LLP of the reservoir. In the latter, despite lower values of the Shannon index and lower number of taxa than in the URP, the bottom fauna was still relatively diverse and abundant, albeit dominated by taxa resistant to unfavourable environmental conditions.

The specificity of the WDR is likely to contribute to the unusually high abundance of bottom fauna, as compared to other reservoirs. It can be assumed that this could be a consequence of the relatively high water dynamics near the bottom, which prevents long-term, acute oxygen deficits, which in turn enables benthic taxa resistant to the lower water oxygenation to achieve such a high abundance.

\section{References}

Ali A, Frouz J, Lobinske RJ. 2002. Spatio-temporal effects of selected physico-chemical variables of water, algae and sediment chemistry on the larval community of nuisance Chironomidae (Diptera) in a natural and a man-made lake in central Florida. Hydrobiologia 470: 181-193.

Angradi TR., Pearson MS., Bolgrien DW., Jicha TM., Taylor B.H, Hill DL. 2009. Multimetric macroinvertebrate indices for midcontinent US great rivers. J N Am Bentho Soc 28: 785-804.

Armitage PD, Cranston PS, Pinder LCV. 1995. The Chironomidae biology and ecology of non-biting midges, Chapman and Hall, London, $572 \mathrm{p}$.

Baker AS, McLachlan AJ. 1979. Food preferences of Tanypodinae larvae (Diptera. Chironomidae). Hydrobiologia 62: 283-288.

Behrend RDL, Takeda AM, Gomes LC, Fernandes SEP. 2012. Using oligochaeta assemblages as an indicator of environmental changes. Braz J Biol 72: 873-884.

Beisel JN, Usseglio-Polatera P, Moreteau JC. 2000. The spatial heterogeneity of a river bottom. a key factor determining macroinvertebrate communities. Hydrobiologia 422: 163-171.

Berg K, Jonasson PM, Ockelmann KW. 1962. The respiration of some animals from the profundal zone of a lake. Hydrobiologia 19: 1-40.

Berg MB. 1995. Larval food and feeding behaviour. In: Armitage PD., Cranston PS. and Pinder LCV. eds. The Chironomidae. Biology and Ecology of non-biting midges, Chapman and Hall, London, pp. 136-168.

Brinkhurst RO. 1969. Changes in benthos in lakes Erie and Ontario. Bull Buffalo Soc.Nat Sci 25: 45-65.

Callisto M, Goulart M, Barbosa FAR, Rocha O. 2005. Biodiversity assessment of benthic macroinvertebrates along a reservoir cascade in the lower São Francisco river (northeastern Brazil). Braz J Biol 65: 229-240.

Ciutat A, Weber O, Gerino M, Boudou A. 2006. Stratigraphic effects of tubificids in freshwater sediments: a kinetic study based on Xray images and grain-size analysis. Acta Oecol 30: 228-237.

Corbi JJ, Trivinho-Strixino S. 2002. Spatial and bathymetric distribution of the microbenthic fauna of the Ribeirao das Anhumas reservoir (Americo Brasieliense-SP, Brasil). Acta Limnol Bras 14: 35-42.

Di Giovanni MV, Goretti E, Tamanti V. 1996. Macrobenthos in Montedoglio Reservoir, central Italy. Hydrobiologia 321: 17-28.

dos Santos NCL, de Santana HS, Dias RM, et al. 2016. Distribution of benthic macroinvertebrates in a tropical reservoir cascade. Hydrobiologia, 765, 265-275.

Dudgeon D. 2010. Prospects for sustaining freshwater biodiversity in the 21 st century: linking ecosystem structure and function. Current Opin Env Sust 2: 422-430.
Dumnicka E. 1993. Profundal macrofauna of the Dobczyce Reservoir [southern Poland] in the fifth year after its filling. Acta Hydrobiol 35: 329-340.

Dumnicka E, Zięba J, Żurek R. 1986. Characteristics of zooplankton and macrobenthos in the Rożnów dam reservoir (Southern Poland). Acta Hydrobiol 28: 393-413.

Dusoge K. 1989. Distribution and structure of benthos in the lowland Zegrzyński Reservoir. Ekol Pol 37: 281-298

Dusoge K, Bownik-Dylińska L, Ejsmont-Karabin J, Spodniewska I, Węgleńska T. 1985. Plankton and benthos of man-made Lake Zegrzyńkie. Ekol Pol 33: 455-479.

Dusoge K, Lewandowski K, Stańczykowska A. 1990. Liczebnosć i biomasa fauny dennej $\mathrm{w}$ różnych srodowiskach Zbiornika Zegrzyńskiego. In: Kajak Z. ed. Funkcjonowanie ekosystemów wodnych, ich ochrona i rekultywacja. Częsć I, Ekologia zbiorników zaporowych i rzek, SGGW-AR, Warszawa, pp. $57-$ 85. (in Polish)

Fleituch T. 2000. Fauna denna. In: Starmach J. and MazurkiewiczBoroń G. eds. biornik Dobczycki. Ekologia-Eutrofizacja-Ochrona, Zakład Biologii Wód im. Karola Starmacha PAN, Kraków, pp. 112-135.

Friedl G, Wüest A. 2002. Disrupting biogeochemical cycles Consequences of damming. Aquat Sci 64: 55-65.

Gillespie BR, Brown LE, Kay P. 2014. Effects of impoundment on macroinvertebrate community assemblages in upland streams. River Res Appl 31: 953-963.

Giziński A, Wolnomiejski N. 1982. Zoobenthos of Koronowo Dam Reservoir in its 10th and 15th year of existence. AUNC, Nauki Mat. -Przyr., Zeszyt 52, Prace Limnologiczne nr 13

Giziński A, Błędzki LA, Kentzer A, Wisniewski A, Żytkowicz R. 1989. Hydrobiological characteristic of the lowland, rheolimnic Włocławek Reservoir on the Vistula River. Ekol Pol 37: 359-403.

Gong Z, Xie P. 2001. Impact of eutrophication on biodiversity of the macrozoobenthos community in a chinese shallow lake. $J$ Freshwater Ecol 16: 171-178.

Gore JA, Layzer JB, Mead J. 2001. Macroinvertebrate instream flow studies after 20 years: a role in stream management and restoration. Regul River 17: 527-542.

Grigelis A. 1990. Productivity and production of oligochaete Potamothrix hammoniensis in water bodies of the area its distribution. Supplement to Acta Hydrobiologica Lituanica 1-23.

Grzes M. 1983. Niektóre problemy stopnia wodnego "Włocławek" i jego zbiornika. Czas Geogr 54: 439-457 (in Polish)

Grzybowska B. 1965. The bottom fauna of the Rożnów dam reservoir 21 years after its filling. Kom Zagosp Ziem Górskich PAN 11: 281288.

Hakanson L, Jansson N. 1983. Principles of lake sedimentodology, Sringer-Verlag, Berlin, 316 p.

Han BP. 2010. Ecology of reservoirs in China. Review and prospects. J Lake Sci 22: 151-160.

Humphries P, Keckeis H, Finlayson B. 2014. The river wave concept. integrating river ecosystem models. BioScience 64: 870-882.

Johnson RK, Bostrom B, van de Bund W. 1989. Interaction between Chironomus plumosus (L.) and the microbial activity in surficial sediments of a shallow lake. Limnol Oceanogr 34: 992-1003.

Jorcin A, Nogueira MG, Belmont R. 2009. Spatial and temporal distribution of the zoobenthos community during the filling up period of Porto Primavera Reservoir (Paraná River, Brazil). Braz J Biol 69: 19-29.

Jurkiewicz-Karnkowska E. 1989. Occurrence of molluscs in the littoral zone of the Zegrzyński Reservoir and in the pre-mouth and mouth zones of supplying rivers. Ekol Pol 37: 319-336. 
Kajak Z. 1962. Przegląd pismiennictwa dotyczącego bentosu zbiorników zaporowych w związku z budową zbiornika Dębe na Bugu i Narwi. Ekol Pol Ser B 8: 3-27. (in Polish)

Kajak Z. 1989. Ecology of lowland Zegrzyński reservoir near Warsaw, Poland. Arch Hydrobiol Beih Ergebn Limnol 33: 841-850.

Kajak Z, Prus P. 2001. Effects of the density of larvae and type of substrate on Chironomus plumosus (L.) (Diptera. Chironomidae) population. Laboratory experiments. Pol J Ecol 49: 369-378.

Kajak Z, Prus P, 2003. Seasonal and year-to-year variation of numbers of Chironomus plumosus L. and Tubificidae in a lowland reservoir: regularities, causes, mechanisms. Pol J Ecol, 51: 339 351.

Kakareko T. 2000. Ekologia leszcza (Abramis brama L.) w Zbiorniku Włocławskim [Ecology of bream (Abramis brama L.) in Włocławek Dam Reservoir]. PhD Thesis, University Nicolai Copernici, Toruń, Poland.

Kasprzak K. 1981. Skąposzczety wodne. Klucze do oznaczania bezkręgowców Polski, Tom 4, PWN, 226 p. (in Polish)

Kentzer A, Giziński A, Mieszczankin T. 1999. Hydrochemistry of the Lower Vistula River in the section Płock-Torun during the period 1986-1995. The influence of the Włocławek Dam Reservoir on water quality. Acta Univ Nicolai Copernici Limnol Papers 20: 1324.

Kimmel BL, Lind OT, Paulson LJ. 1990. Reservoir primary production. In: Thornton KW, Kimmel BL and Payne FE eds. Reservoir limnology: ecological perspectives, John Wiley and Sons, Inc., pp. 133-193.

Krzyżanek E. 1971. Bottom fauna in the Tresna dam reservoir in 1966. Acta Hydrobiol 13: 335-342.

Krzyżanek E. 1976. Preliminary investigations on bivalves (Bivalvia) of the dam reservoir at Goczałkowice. Acta Hydrobiol 18: 61-73.

Krzyżanek E. 1977. Bottom macrofauna of the dam reservoir at Goczałkowice Poland in the years 1970-1975. Acta Hydrobiol 19: 51-68.

Kudelska D, Soszka H. 1996. Przegląd stosowanych w różnych krajach sposobów oceny I klasyfikacji wód powierzchniowych, Biblioteka Monitoringu S rodowiska, PIOS, Warszawa, 83 p. (in Polish)

Kuklińska B. 1992. Chironomidae communities of the near-shore zone in Zegrzyński Reservoir, Poland. Neth J Aquat Ecol 26: 385 392.

Liu QG, Zha YT, Hu ZJ. 2011. Chapter 9, Spatial distribution of macrozoobenthos in a large and deep impoundment. Xin'anjiang Reservoir, Zhejiang Province. In: Han BP. and Liu Z. eds.Tropical and Sub-Tropical Reservoir Limnology in China 91, Springer, Dordrecht, Netherlands, pp. 135-153.

Liu XQ, Wang HZ. 2007. Food composition and dietary overlap of macroinvertebrates in a shallow eutrophic lake in China: spatial and temporal variations. Fund Appl Limnol 168: 71-82.

Martínez A, Larrañaga A, Basaguren A, Pérez J, Mendoza-Lera C, Pozo J. 2013. Stream regulation by small dams affects benthic macroinvertebrate communities. From structural changes to functional implications. Hydrobiologia 711: 31-42.

McEwen DC, Butler MG. 2010. The effects of water-level manipulation on the benthic invertebrates of a managed reservoir. Freshw Biol 55: 1086-1101.

Milbrink G, Timm T. 2001. Distribution and dispersal capacity of the Ponto-Caspian tibificid oligochaete Potamothrix moldaviensis Vejdovský et Mrázek, 1903 in the Baltic Sea Region. Hydrobiologia 463: 93-102.

Moreno P, Callisto M. 2006. Benthic maroinvertebrates in the watershed of an urban reservoir in southeastern Brazil. Hydrobiologia 560: 311-321.
Moretto Y, Higuti J, Takeda AM. 2003. Spatial variation of the benthic community in the Corumbá reservoir, Goiás, Brazil. Acta Scientiarum Biolog Sci 25: 23-30.

Myers N, Mittermeier RA, Mittermeier CG, Fonseca GAB, Kent J. 2000. Biodiversity hotspots for conservation priorities. Nature 403: 853-858.

Nyman M, Korhola A, Brooks SJ. 2005. The distribution and diversity of Chironomidae (Insecta. Diptera) in western Finnish Lapland, with special emphasis on shallow lakes. Global Ecol Biogeogr 14: 137-153.

Ogbeibu AE, Oribhabor BJ. 2002. Ecological impact of river impoundment using benthic macro-invertebrates as indicators. Water Res 36: 2427-2436.

Olden JD, Naiman RJ. 2010. Incorporating thermal regimes into environmental flow assessments: modifying dam operations to restore freshwater ecosystem integrity. Freshwater Biol 55: 86-107.

Olszewski Z, Mówińska G. 1985. Composition particle size and organic matter content of the bottom sediments of man made lake Zegrzyńskie Poland. Ekol Pol 33: 481-498.

Pamplin PAZ, Almeida TCM, Rocha O. 2006. Composition and distribution of benthic macroinvertebrates in Americana Reservoir (SP, Brazil). Acta Limnol Bras 18: 121-132.

Pelletier MC, Gold AJ, Heltshe JF, Buffum HW. 2010. A method to identify estuarine macroinvertebrate pollution indicator species in the Virginian Biogeographic Province. Ecol Indicators 10: 1037 1048.

Petridis D, Sinis A. 1993. Benthic macrofauna of Tavropos reservoir (central Greece). Hydrobiologia 262: 1-12.

Phillips ID, Pollock MS, Bowman MF, McMaster G, Chivers DP. 2015. Thermal alteration and macroinvertebrate response below a large Northern Great Plains Reservoir. J G Lake Res 41: 155-163.

Piechocki A. 1979. Mięczaki (Mollusca). S limaki (Gastropoda). Fauna Słodkowodna Polski, PWN, Warszawa-Poznań. (in Polish)

Piechocki A, Dyduch-Falniowska A. 1993. Mięczaki (Mollusca). Małże (Bivalvia). Fauna słodkowodna Polski [Molluscs. Bivalves. Freshwater fauna of Poland], 7A - PWN, Warszawa, 200 p. (in Polish)

Płużański A, Półtorak T, Tomaszek J, Granops M, Żurek R, Dumnicka E. 1990. Charakterystyka limnologiczna zbiorników Górnego Sanu (Solina-Myczkowce). In: Kajak Z. ed. Funkcjonowanie ekosystemów wodnych, ich ochrona i rekultywacja. Cz. I. Ekologia zbiorników zaporowych i rzek, SGGW-AR, Warszawa, pp. 276279. (in Polish)

Poff NL, Zimmerman JKH. 2010. Ecological responses to altered flow regimes: a literature review to inform the science and management of environmental flows. Freshwater Biol 55: 194-205.

Popp A, Hoagland KD. 1995. Changes in benthic community composition in response to reservoir aging. Hydrobiologia 306: 159-171.

Prat N, Real M, Rieradevall M. 1992. Benthos of spanish lakes and reservoirs. Limnetica 8, 221-229.

Prus P. 2006. Bentos strefy pozalitoralowej Zbiornika Siemianówka. In: Górniak A. (ed.), Ekosystem Zbiornika Siemianówka, Uniwersytet w Białymstoku, Białystok 168-175. (in Polish)

Prus P. 2009. The dependencies between the abundance of Chironomus f. 1. plumosus and bream (Abramis brama) net catches in a lowland reservoir (Zegrzyński Reservoir, central Poland). Oceanol Hydrobiol St 38: 15-30.

Prus P, Wis niewolski W. 2005. Zróżnicowanie bazy pokarmowej ryb w górskim i nizinnym zbiorniku zaporowym i jego konsekwencje dla składu ichtiofauny. In: Mickiewicz M. and Wołos A. eds. Rybactwo w jeziorach, rzekach i zbiornikach zaporowych w 2004 roku, IRS Olsztyn, 87-106. (in Polish) 
Puczyńska I. 2004. Różnorodnos ć biologiczna fauny dennej i jej rola w kształtowaniu szlaków biogenów w zbiorniku Sulejowskim. Master Thesis, Uniwersytet Lódzki. (in Polish)

Richter BD, Mathews R, Harrison DL, Wigington R. 2003. Ecologically sustainable water management: managing river flows for ecological integrity. Ecol. Appl 13: 206-224.

Rieradevall M. 1991. Benthic fauna of Banyoles lake. Verh Internat Verein Limnol 24: 1020-1023.

Risnoveanu G, Vadineanu A. 2002. Observations on the population dynamics of Potamothrix hammoniensis (Michaelsen, 1901) (Tubificidae, Oligochaeta) in Lake Isacova, in the Danube Delta. Hydrobiologia 479: 23-30.

Rosenberg DM, Resh VH. 1993. Introduction to freshwater biomonitoring and benthic macroinvertebrates. In: Rosenberg DM. and Resh VH. eds. Freshwater Biomonitoring and Benthic Macroinvertebrates, Chapman and Hall, New York, pp. 1-9.

Shao M, Xie Z, Han X, Cao M, Cai Q. 2008. Macroinvertebrate community structure in Three-Gorges Reservoir, China. Internat Rev Hydrobiol 93: 175-187.

Smiljkov S, Slavevska-Stamenković V, Prelić D, Paunović M. 2008. Distribution of benthic macroinvertebrates in Mantovo Reservoir (South-East part of the R. Macedonia), Conference paper, BALWOIS 2008, Ohrid, Republic of Macedonia, 27-31 May 2008.

Sokolova NYu. 1983. Chironomus plumosus L. (Diptera. Chironomidae). Systematics, morphology, ecology, production, Izd. Nauka, Moskwa, 309 p.

Starmach K. 1958. Hydrobiologiczne podstawy użytkowania przez wodociągi łytkich zbiorników rzecznych. Pol Arch Hydrobiol 4: 96. (in Polish)

Thornton KW. 1990. Sedimentary processes. In: Thornton KW, Kimmel BL. and Payne FE., eds. Reservoir limnology: ecological perspectives, A Wiley-Interscience Publication John Wiley and Sons, Inc., New York, 43-69.
Thornton KW, Kennedy RH, Carroll JH, Walker WW, Gunkel RC, Ashby S. 1981. Reservoir sedimentation and water quality - an heuristic model. In: Stefan HG, ed. Proceedings of the symposium on surface water impoundments, Am. Soc. Civil Engr., New York, pp. 654-661.

Timm T. 1970. On the fauna of the Estonian Oligochaeta. Pedobiologia 10: 52-78.

Ward JV, Stanford JA. 1983. The serial discontinuity concept of lotic ecosystems. In: Fontaine TD. and Bartell SM., eds. Dynamics of Lotic Ecosystems. Ann Arbor Sciences, Ann Arbor, 29-42.

Wiederholm T. 1983. Chironomidae of the Holarctic region. Keys and diagnoses. Part 1. Larvae, Entomol. Scand 19: 457

Wills TC, Baker EA, Nuhfer AJ, Zorn TG. 2006. Response of the benthic macroinvertebrate community in a northern Michigan stream to reduced summer streamflows. River Res Appl 22: 819836.

Ye L, Han X, Xu Y, Cai Q. 2007. Spatial analysis for spring bloom and nutrient limitation in Xiangxi bay of Three Gorges Reservoir. Environ. Monit Assess 127: 135-145.

Zhang M, Shao ML, Xu YY, Cai QH. 2010. Effect of hydrological regime on the macroinvertebrate community in Three-Gorges Reservoir, China Quat Int 226: 129-135.

Żbikowski J, Kakareko T, Poznańska M, Kobak J. 2007. Malacofauna of two hydrologically different habitats in the near-shore zone of the Włocławek Dam Reservoir (Vistula River, Poland). Folia Malacologica 15: 25-38.

Żytkowicz R, Błędzki L, Kentzer A, Wisniewski R, Giziński A, Żbikowski J. 1990. Zbiornik Włocławski. Ekologiczna charakterystyka pierwszego zbiornika zaporowego planowanej kaskady dolnej Wisły. In: Kajak Z. ed. Funkcjonowanie ekosystemów wodnych, ich ochrona i rekultywacja. I. Ekologia zbiorników zaporowych i rzek, SGGW-AR, Warszawa, 201-225. (in Polish)

Cite this article as: Mimier D, Żbikowska E, Żbikowski J. 2018. Water residence time in the Włocławek dam reservoir (the Vistula river, Poland) affects its macrozoobenthos structure. Ann. Limnol. - Int. J. Lim. 54: 24 